\title{
The Determinations of East Asia's Automobile Trade Using a Gravity Model
}

\author{
Shahrun Nizam Abdul-Aziz ${ }^{1}$, Normala Zulkifli ${ }^{1}$, Norimah Rambeli@ Ramli ${ }^{1}$, Noor Al-Huda Abdul Karim ${ }^{1}$, Zainizam \\ Zakariya $^{1} \&$ Norasibah Abdul Jalil ${ }^{1}$ \\ 1 Faculty of Management and Economics, Universiti Pendidikan Sultan Idris, 35900 Tanjong Malim, Perak, \\ Malaysia \\ Correspondence: Shahrun Nizam Abdul-Aziz, Faculty of Management and Economics, Universiti Pendidikan Sultan \\ Idris, 35900 Tanjong Malim, Perak, Malaysia. E-mail: shahrun@ fpe.upsi.edu.my
}

Received: October 10, 2019

Accepted: November 5, 2019

Online Published: December 23, 2019

doi:10.5430/rwe.v10n5p113

URL: https://doi.org/10.5430/rwe.v10n5p113

\begin{abstract}
The aim of this study is to investigate empirically the factors that determine the level of automobile trade in East Asian countries by taking into account government policies as well as the role of MNEs. To do so, in this study we include dummies of import substitution industrialisation (ISI) and export orientation industrialisation (EOI) policies as well as Japanese FDI as additional explanatory variables in our augmented gravity models. We found that GDPs, distance, per capita income, FTA, government policies, language and FDI are the determinants for the development of automobile industry in each country in East Asia. In the case of auto P\&C, apart from economic size, the role of government through trade policy (i.e., FTA) and industrial policies as well as the role of MNCs are the major contributors to the development both exports and imports of East Asian countries. In the case of final automobiles, the role of FTA and language seems to be unimportant. Nonetheless, the role of government policies and MNCs seem to be important.
\end{abstract}

Keywords: East Asian, trade, automobiles, parts and components, gravity model, import substitution industrialization, export orientation industrialization

\section{Introduction}

The development of Japanese auto industry has begun before the World War II and now Japan has become one of the world's leading auto manufacturers. Apart from being the leading auto producer, Japan is also plays a pivotal role either directly or indirectly in the production of automobiles in many countries particularly in the East Asian region. The involvement of Japanese auto manufacturers in East Asian countries has led to the development of the auto industry in those countries. This development continues to evolve to meet the expansion of domestic demand, as well as to enhance exports. To enable the development of the automobile industry in this region to continue to grow, government policies relating to the industry are a leading exponent of the development of the industry. According to the Asia Automotive Industry (2012), the region's largest population, i.e. Indonesia, has begun to implement policies that promote the production and sale of low-cost vehicles for the purpose of maximising growth for the auto parts and final automobiles manufacturing industries. At the same time, countries such as Malaysia, the Philippines and Vietnam are looking for growth strategies to ensure the survival of their automobile industry. Meanwhile, the Republic of Korea is conducting the policy of expanding overseas markets as well as focusing on the development of environmentally-friendly vehicles, such as electric and hybrid cars (Stanciu et al., 2018).

Apart from state policies, the role of Japanese affiliate firms in Asian countries is also said to have a significant impact on the development of the automobile in many countries in East Asia (Note 1). Many countries in East Asia, such as Thailand, the Philippines and Indonesia, rely heavily on foreign technology and capital, especially from Japan, to develop their automobile industry and almost 90 percent of market share in those countries is occupied by Japanese assemblers (Japanese Automotive Parts Industry, 2005). The Japanese participation in the East Asian automobile industry is through FDI and/or Joint Venture and this has brought together financial resources, management know-how and other externalities such as knowledge spillovers to these countries. Moreover, Japanese firms such as Toyota and Mitsubishi have relationships with, and also provide technical assistance to, the local assemblers in these countries. 
Over the last three decades, the East Asian region has experienced a massive expansion of International Production Networks (IPNs) which coincided with a significant change in the structure and nature of East Asia's trade networks. These changes are due to the action of foreign firms who extended the geographic coverage of their production activities and at the same time integrated their old stand-alone operations in individual host countries into complex IPNs (Ernst, 1997; Okon, 2017). These circumstances have led many researchers (such as Athukorala and Yamashita, 2006; Athukorala, 2010; Athukorala \& Menon, 2010; Clark, 2010; Kimura, 2006 \& 2008; Kimura \& Obashi, 2010 \& 2011 and Shepherd, 2010) to study the determinants of IPNs' development in East Asia. In addition, previous studies on the determinants of IPNs in automobile have given less attention to the role played by governments and Japanese MNCs.

The aim of this study is to investigate empirically the factors that determine the level of automobile trade in East Asian countries by taking into account the government policies as well as the role of MNEs. To do so, in this study we include dummies of import substitution industrialisation (ISI) and export orientation industrialisation (EOI) policies as well as Japanese FDI as additional explanatory variables in our augmented gravity models.

This paper is divided into six sections which are structured as follows: Section 2 discusses some important facts related to gravity model (Note 2). Section 3 discusses data description and sources. Sections 4 and 5 respectively discuss methodology and estimation results. Sections 6 concludes this paper.

\section{The Gravity Model}

In fact, the gravity model is derived from the Newton's 1687 "Law of Universal Gravitation". This law in mechanics states that the gravitational force, $F_{i j}$ (in newtons), between two objects is proportional to the product of each body's mass, $M_{1}$ and $M_{2}$ (in kg) divided by the square of the distance between their respective centres of gravity (in metres);

$$
F_{i j}=G \frac{M_{1} M_{2}}{D_{i j}^{2}}
$$

Later on, in the 1860s, H. Carey first introduced this law into the study of human behaviour and since then the gravity model has been widely used in the social sciences (Cheng and Wall, 2005; Zhang, 2018). In economics, the gravity model of international trade was first applied by Tinbergen (1962) and Pöyhönen (1963) and since then it has also been applied with a lot of empirical success in the study of migration, tourism and investment.

The gravitational law of trade can be expressed in much the same notation as model (1), except that $\mathrm{M}_{\mathrm{i}}$ and $\mathrm{M}_{\mathrm{j}}$ are redefined as the "economic mass" of the two countries. In this respect, "the trade flow between two countries is assumed to be proportional to the product of each country's 'economic mass' generally measured by GDP, each to the power of quantities to be determined, divided by the distance between the countries' respective 'economic centre of gravity', generally their capitals, raised to the power of another quantity to be determined" (Christie, 2002). The model can then be generalised as:

$$
M_{i j}=K(G D P)_{i}^{\beta_{1}}(G D P)_{j}^{\beta_{2}}(D i s)_{i j}^{\beta_{3}}
$$

where:

$M_{i j} \quad:$ the amount of imports into country i from country j

$G D P_{i} \quad$ : countryi's GDP

$G D P_{j} \quad$ : countryj's GDP

Dis $\quad$ : geographical distance between the countries' capitals.

Model (2) can be expressed in the linear form as follows:

$$
\ln X M_{i j}=\alpha+\beta_{1} \ln \left(G D P_{i}\right)+\beta_{2} \ln \left(G D P_{j}\right)+\beta_{3} \ln \left(D i s_{i j}\right)+\mu_{i j}
$$


where $\mu_{i j}$ is an additive disturbance term and $\alpha=\ln (\mathrm{K})$. This baseline model gives relatively good results to the estimation. However, there are other factors that also influence trade levels. Linnemann (1966) developed an augmented gravity model by adding population as an additional measure of economic size. It is also common to use per capita income instead of population in the augmented gravity model to capture the size effect, for example Frankel and Wei (1998). A certain number of dummy variables that test for specific effects such as sharing a common border, speaking the same language, being a member of a trade agreement are also added in most estimates of gravity models.

Criticism of the gravity model due to the absence of a theoretical background ended when a solid theoretical underpinning of the model was established by Anderson (1979) and Bergstrand (1985) (Note 3). Anderson (1979) was the first to provide a clear micro-foundation by resting on Armington's assumption which assumes that products are differentiated by country of origin. In other words, this assumption argued that two products with the same kind but originating from different nation are imperfect substitutes in demand. Anderson's (1979) theoretical derivation of the gravity modelling develops gradually. Initially, he developed a simplest gravity model by assuming that there exist two countries and each of which producing one differentiated product. There is no tariff or transport costs exist. The model also assumes that both countries have identical Cobb-Douglas preferences. In this respect, the share of income spent on tradable product is the same for both countries.

Anderson (1979) then strives for more accurate representation of trade flows by relaxing the assumption of producing one differentiated product and allowing the two countries to produce tradable and non-tradable products. This modified model postulates identical Cobb-Douglas or constant elasticity of substitution (CES) preference function for all countries and weakly separable utility functions between traded and non-traded goods. Here, utility maximisation with respect to income constraint gives traded goods shares that are a function of traded goods prices only. Prices are constant in cross sections, so using the share relationships along with trade (im)balance identity, country $j$ 's imports of country $i$ 's goods are obtained. Then, assuming log linear functions in income and population for shares, the gravity model for aggregate imports is obtained.

In addition, Anderson (1979) also noted the endogeneity problem of income and proposed two alternative solutions which follow the Instrumental Variable (IV) approach, employing different instruments as follows: (1) employs the lagged values of income as instruments; or (2) employs first stage estimations of shares by OLS and substitute income values obtained from the estimated share for a second stage re-estimation of the gravity equation. For many goods, the aggregate gravity equation is obtained only by substituting a weighted average for the actual shares in the second shares. By using CES preferences over Armington-differentiated goods Bergstrand (1985); Aldulaimi (2018) derived a reduced-form equation for bilateral trade, involving price indices. He then estimated the system in order to test the assumption of product differentiation using GDP deflators to approximate these price indices. For richness, the CES preferences were also nested with different elasticity substitution among imports and then between imports and domestic goods.

\section{Data Description and Sources}

The countries involved in this analysis are Japan, China, the Republic of Korea, Thailand, Indonesia, Malaysia, the Philippines, Singapore and Vietnam, while their main trading partners other than the above countries are listed in Table 1 (Note 4). Data for this analysis are taken from the years 1990 to 2015. 
Table 1. List of countries chosen for the empirical studies

\begin{tabular}{lll}
\hline Country & & Country \\
\hline China & Australia & Netherlands \\
Indonesia & Austria & New Zealand \\
Japan & Belgium & Norway \\
Republic of Korea & Brazil & Oman \\
Malaysia & Canada & Pakistan \\
Philippines & Chile & Panama \\
Thailand & China & Philippines \\
Vietnam & Denmark & Portugal \\
& Finland & Russian Federation \\
& France & Saudi Arabia \\
& Germany & Singapore \\
& Greece & South Africa \\
& India & Spain \\
& Indonesia & Sweden \\
& Ireland & Switzerland \\
& Israel & Thailand \\
& Italy & Turkey \\
& Japan & United Arab Emirates \\
& Rep. of Korea & United Kingdom \\
& Kuwait & United States \\
& Malaysia & Vietnam \\
& Mexico & \\
& & \\
& & \\
& & \\
& & \\
& & \\
& & \\
& & \\
& &
\end{tabular}

\subsection{Trade Data}

Data for dependent variables (i.e. export of auto P\&C, import of auto P\&C, export of final automobiles and import of final automobiles), in current US dollars are collected from UN Comtrade. These data have been reconciled to overcome the problem of inconsistent data reported by exporters and importers. In addition, we used SITC Revision 2 to classify the commodity group and based on this classification the data have been divided into auto P\&C and final automobiles. Commodities included under auto P\&C are chassis, bodies, and other parts and accessories, while commodities under final automobiles comprise track-laying tractors, wheeled tractors, passenger vehicles, goods-transport vehicles, special purpose vehicles, public service vehicles and road tractors.

\subsection{Gross Domestic Product (GDP $P_{i j t}$ and $\left.G D P_{i j t}\right)$}

In this study we use the GDP of countries $i$ and $j$ as a proxy of economic size. Based on the modern trade theory, a country will trade with big economies rather than small ones. This is because big economies will typically have a greater variety of products and consumers like variety. In addition, larger markets have a great demand for foreign goods. Data for $G D P_{i}$ and $G D P_{j}$ (in current US dollars) are obtained from the World Development Indicators (WDI). In this study, we expect a positive sign for the coefficients of both $G D P_{i}$ and $G D P_{j}$. This is because the bigger country $i$ 's GDP the bigger the volume and varieties of its national outputs and the greater the scope of its exports. Likewise, the bigger country $j$ 's GDP, the bigger demand it can make for imports.

\subsection{Geographical Distance (Dis $s_{i j}$ )}

In this study we use distance as a proxy of transport costs and other costs that are related to trade obstacles, such as insurance, policy barriers, etc. The proximity measurement used in this study is the direct distance of capital between two countries (countries $i$ and $j$ ) in kilometres. Data for distance were obtained from the CEPII database. We expect a negative sign for coefficient of $D i s_{i j}$. This is because the closer the distance between partner countries, the more familiar they are with each other's taste and preferences and the higher their trade flows will be. In contrast, the larger the distance between partner countries, the larger the trade cost between them and consequently the larger the trade obstacle between them. 


\subsection{Per Capita Income $\left(P C Y_{i}\right.$ and $\left.P C Y_{j}\right)$}

Many studies that use the gravity approach incorporate the per capita income of exporting and importing countries when estimating the model (Note 5). In general, the higher per capita income countries trade more as they have a better quality of transportation infrastructure (viz. roads, railways, ports, airports, etc.). In addition, imports of automobiles are income elastic where greater demand from countries with higher living standard. It also suggested that the more similar the per capita income between two countries is, the more similar the demand structure between them. This means that two countries with similar per capita income will trade more amongst themselves. In this study, the values of per capita income have been calculated using the following formula:

$$
P C Y=\frac{G D P}{\text { Population }}
$$

PCYs can be positive or negative. If a country enjoys the economies of scale effect with a higher per capita income then the coefficient for $P C Y_{i}$ will be positive. In contrast, if a country exports less due to the absorption effect then the coefficient of $P C Y_{i}$ will be negative. Similarly, if country $j$ demands more of country $i$ 's goods due to higher income, then the coefficient for $P C Y_{j}$ will be negative. On the other hand, due to the economies of scale effect in country $j$, if more goods are produced in country $j$, then the coefficient of $P C Y_{j}$ will be negative.

\subsection{Absolute Different in Per Capita Income ( $\left.\left|\triangle P C Y_{i j}\right|\right)$}

The aim of including this variable in the model is to capture the differences in factor endowment between pair countries in explaining trade. Based on the $\mathrm{H}-\mathrm{O}$ hypothesis, the larger the differences in the factor endowments between two countries, the larger will be the trade between them. In this respect, the sign of $\left|\triangle P C Y_{i j}\right|$ would be positive if the H-O hypothesis holds. On the other hand, based on Linder hypothesis demand structure will be similar for the similarities of per capita income. In other words, the similar the countries' per capita income, the larger the bilateral trade between them. In this respect, the sign of $\left|\Delta P C Y_{i j}\right|$ would be negative if this hypothesis holds. In this paper, we used the following formula to calculate absolute differences in per capita income.

$$
\left|\Delta P C Y_{i j}\right|=\left|P C Y_{i}-P C Y_{j}\right|
$$

\subsection{Common Border $\left(\right.$ BOR $\left._{i j}\right)$}

In this study we include the common border to capture other possible additional advantages of proximity that are not captured by the distance variable. The value of one will be given if two countries share the same land border and zero otherwise. Data for the common border are taken from The World Factbook. We expect $B O R_{i j}$ to have a positive sign because neighbouring countries incur lower transport costs.

\subsection{Common Language $\left(L A N_{i j}\right)$}

The common language variable is included in our model as we expect countries that speak the same language will trade more. Moreover, Head (2003) argued that two countries that speak the same language trade twice to three times as much as pairs that do not share a common language. In this study, pair countries that share a common language will take a value of one, while those pairs that do not share a common language will take a value of zero otherwise. Data for common language are obtained from the CEPII database. We expect $L A N_{i j}$ to have a positive sign as there is a possibility that the use of the same common language can facilitate trade by reducing transaction costs and aiding better understanding of each other's culture and legal system.

\subsection{Free Trade Agreement $\left(F T A_{i j}\right)$}

Free trade agreements such as ASEAN, the EU and NAFTA have proliferated in the last 20 years and have been widely used in the gravity model by many authors. According to Head (2003), FTAs on average could raise trade about 50 percent. He also pointed out that recent studies found that FTAs have increased trade between partners as much as three times. In this study, we include this variable to capture the implication of membership of a trade 
agreement. The dummy variable takes the value of one if both countries in a given pair belong to the same FTA and zero otherwise. We expect $F T A_{i j}$ to have a positive sign as FTA tends to generate more trade among its members.

\subsection{Dummy of Import Substitution Industrialisation Policy $\left(\operatorname{ISI}_{i t}\right)$}

The governments in East Asian countries have taken various measures through policies and legislation to shape and facilitate the development of their automobile industries. Some countries still implementing inward-oriented strategies, while the others have implemented outward-oriented strategy. There is also the case that a country implementing both strategies at the same time. Bruton (1989) defines ISI as a development strategy carry out by developing countries to achieve two goals: (1) to learn industrialisation experience from developed countries (Note 6); (2) to protect their domestic industries from competition of imported products. Through this strategy a country will replace imports of certain products with domestic products. This means that certain products that were previously imported will not be imported in the same amount.

In this study, the dummy will take the value of one if a country implementing ISI policy in a particular year and zero otherwise. A country is considered implementing ISI policy in a particular year based on the information of its local content requirement, import tariff, exchange rate policy or import licensing requirement. In the export side, we expect $I S I_{i t}$ to have a negative sign. This is because, when a country changes its policy from ISI to EOI, its exports would increase. In the import side, however, the sign of coefficient for $I S I_{i t}$ is expected to have a positive sign. This is because, when a country changes its policy from ISI to EOI, the country becomes more competitive in producing automobile products and consequently its imports would decrease.

\subsection{Dummy of Export Orientation Industrialisation Policy $\left(\right.$ EOI $\left._{i t}\right)$}

In general, EOI is an outward-oriented strategy of industrialisation where a country has focused on the production for foreign market. According to Ballasa (1981), EOI is a development strategy whereby the government implementing a less protectionist or interventionist policy. In this respect, the role of government under this strategy is more on carrying out promotional measures by giving subsidies to overcome various shortcomings that thwart industries to accomplish economies of scale (Karunaratne, 1980). In addition, the government is also provides various facilities such as infrastructure facilities, financial and credit facilities and training for labour.

To identify if a country implementing EOI policy within a certain period, we use export intensity index (EII) (Note 7). The value of one will be given to the dummy of EOI if the value of EII is greater than 10 percent and zero otherwise. In the export side, we would expect $E O I_{i t}$ to have a positive sign. This is because the government that implementing this policy would encourage industry to promote exports. In the import side, however, the sign of coefficient for $E O I_{i t}$ is expected to have a negative sign. This is because, when a country changes its policy from ISI to EOI, its imports would decrease.

\subsection{Japanese Foreign Direct Investment $\left(F D I_{i}\right)$}

The automobile industry in many countries in East Asia still relies heavily on foreign technology and capital, particularly from Japan. According to Dicken (2003), automobile production and sales in East Asia are dominated by Japanese firms. To capture the role of Japanese Multinational Corporations (MNCs) in the development of East Asia's automobile industry we include the variable of Japanese FDI in our model. Data for outward Japanese FDI (in the transport sector) to individuals East Asian countries are obtained from the Ministry of Finance, Japan and the data have been converted to US dollars before being used.

In this study, we have to split data for FDI into two sets i.e., FDI between 1990 and 2004, and FDI between 2005 and 2015. This is because time series data of Japanese FDI outflows are inconsistency due to the action of Japanese Finance Ministry to release BOP-based FDI replacing the old FDI statistics (FDIS) starting from 2005. FDIS and BOP-based FDI have been compiled by mean of different compilation methodologies. In the case of FDIS, the data are obtained from the compilation of figures reported by investors covering only investments over 100 million yen. In contrast, data for the BOP-based FDI are obtained from financial transactions and they are more comprehensive compared to that of FDIS. In addition, data in FDIS always have a positive value as they are generated from the total amount of reported investment by investors. On the other hand, data for the BOP-based FDI are compiled based on accounting rules and they can be recorded in negative values owing to withdrawal of investment. Due to these differences we analysed both type of dataset separately.

The sign of coefficient for Japanese FDI outflows to the individuals East Asian countries can be positive or negative. A positive sign indicates a complementary relationship between FDI and export, while a negative sign indicates a substitution relationship between these two variables. 
3.12 Developing East Asia (DEA) as the Exporter (Importer) of Automobile Product (Ddea(x)_W and Ddea(m)_W) (Note 8)

The automobile industry in DEA continues to grow rapidly particularly in Republic of Korea, Thailand, and China. According to Shimokawa (2010), given the huge of its population DEA has a potential to be the world's largest automobile market. The aim of including this variable in our export (import) models is to capture the role of DEA as the centre of production of Japanese auto P\&C and final automobiles (Shafai et al., 2019).

3.13 Interaction Term Between Japanese FDI Outflow and DEA as the Exporter (Importer) of Automobile Products $\left(l f d{ }^{*} \operatorname{Ddea}(x) \_W\right.$ and $\left.l f d i * \operatorname{Ddea}(m) \_W\right)$

We include these variables in our model to capture the effect of Japanese FDI outflows to the DEA's export (import) for both auto $\mathrm{P} \& \mathrm{C}$, and final automobiles.

Table 1. Summary of the data

\begin{tabular}{|c|c|c|c|}
\hline Group & Variable/Proxy & Formulae & Source \\
\hline \multirow{2}{*}{ Size } & $\mathrm{GDP}_{\text {it }}$ & - & WDI \\
\hline & $\mathrm{GDP}_{\mathrm{jt}}$ & - & WDI \\
\hline $\begin{array}{l}\text { Trade Cost and other } \\
\text { trade obstacles }\end{array}$ & $\mathrm{DIS}_{\mathrm{ij}}$ & - & CEPII \\
\hline \multirow{3}{*}{$\begin{array}{c}\text { Country's } \\
\text { development }\end{array}$} & $\mathrm{PCY}_{\text {it }}$ & $\mathrm{PCY}_{\mathrm{i}}=\mathrm{GDP}_{\mathrm{it}} / \mathrm{POP}_{\mathrm{it}}$ & \multirow{2}{*}{$\begin{array}{c}\text { Author's calculation. Data } \\
\text { for population are taken } \\
\text { from } \\
\text { IFS, IMF }\end{array}$} \\
\hline & $\mathrm{PCY}_{\mathrm{jt}}$ & $P C Y_{j t}=G D P P_{j t} / P_{j t}$ & \\
\hline & $\left|\triangle P C Y_{i j}\right|$ & $\left|\Delta P C Y_{i j}\right|=\left|P C Y_{i}-P C Y_{j}\right|$ & Author's calculation \\
\hline Border effect & $\mathrm{BOR}_{\mathrm{ij}}$ & 1 if common border; 0 otherwise & World Factbook \\
\hline Language effect & LANij & $\begin{array}{l}1 \text { if the two countries share the common } \\
\text { language; } 0 \text { otherwise }\end{array}$ & World Factbook \\
\hline $\begin{array}{c}\text { Trade agreement } \\
\text { effect }\end{array}$ & FTA $_{\text {ijt }}$ & $\begin{array}{l}1 \text { if there is an FTA between country } i \text { and } \\
j ; 0 \text { otherwise }\end{array}$ & $\mathrm{ADB}$ \\
\hline The ISI policy effect & ISI $_{\text {it }}$ & $\begin{array}{l}1 \text { if country i implementing ISI policy; } 0 \\
\text { otherwise }\end{array}$ & Various sources \\
\hline The EOI policy effect & $\mathrm{EOI}_{\mathrm{it}}$ & $\begin{array}{l}1 \text { if country i implementing EOI policy; } 0 \\
\text { otherwise }\end{array}$ & Various sources \\
\hline The role of MNE's & $\mathrm{FDI}_{\mathrm{it}}$ & - & Ministry of Finance, Japan \\
\hline
\end{tabular}

\section{Methodology}

Traditionally cross-section data has been used to estimate trade relationships in a gravity model. However, panel data methodology is now used widely due to some disadvantages of using cross-sectional data. For example, the cross-sectional models unable to control for unobserved invariant heterogeneity and it then generate biased results. 
Panel data methodology can solve the problem of heterogeneity by permitting for individual and year specific effects. In addition, unobserved trading-partner-pairs' individual effects can be monitored when using panel data (Kang et al., 2010 and Song, 2012; CHE and Sundjo, 2018). In this study, we will use the panel data analysis approach for our empirical gravity models.

\subsection{The Estimated Equations}

Using our dataset we estimate four gravity models for East Asia: (1) the gravity model of East Asia's export of auto P\&C, (2) the gravity model of East Asia's import of auto P\&C, (3) the gravity model of East Asia's export of final automobiles, and (4) the gravity model of East Asia's import of final automobiles. The initial step is to regress the basic model as shown by equation (3). The second step is to extend the basic model by adding the country's development variables (i.e. per capita income and absolute difference in per capita income) as well as the dummies of common border, common language, and free trade agreement as shown in equation (6).

$$
\begin{aligned}
\ln X M_{i j}= & \alpha+\beta_{1} l G D P_{i}+\beta_{2} l G D P_{j}+\beta_{3} l D i s_{i j}+\beta_{4} l P C Y_{i}+\beta_{5} l P C Y_{j} \\
& +\beta_{6} \ln \left|\Delta P C Y_{i j}\right|+\beta_{7} B O R_{i j}+\beta_{8} L A N_{i j}+\beta_{9} F T A_{i j t}+v_{1 i j}
\end{aligned}
$$

where;

$P C Y_{i}$ : income per capita of exporting country i.

$P C Y_{j}$ : income per capita of importing country j.

$\left|\triangle P C Y_{i j}\right|:$ absolute different in income per capita between $\mathrm{i}$ and $\mathrm{j}$

$B O R_{i j} \quad$ : dummy of common border.

$\operatorname{LAN}_{i j} \quad$ : dummy of common language

$F T A_{i j t} \quad$ : dummy of free trade agreement

$v_{1 i j}:$ error term.

and the rest of variables and parameter symbols is defined as in equation (3).

In developing model (6) above we followed the specification in Athukorala and Yamashita (2006) (Note 9). The contribution of this study starts in the third step where we add the dummies of ISI and EOI policies to our model to see the effect of those policies in the East Asia's automotive industries. In addition, we also add the Japanese FDI variable as well as interactive variables to capture the role of Multinational Corporations (MNCs). The gravity model of exports became:

$$
\begin{aligned}
\ln X_{i j} & =\alpha+\beta_{1} l G D P_{i}+\beta_{2} l G D P_{j}+\beta_{3} l D i s_{i j}+\beta_{4} l P C Y_{i}+\beta_{5} l P C Y_{j} \\
& +\beta_{6} l\left|\Delta P C Y_{i j}\right|+\beta_{7} B_{i j}+\beta_{8} L A N_{i j}+\beta_{9} F T A_{i j t}+\beta_{10} I S I_{i t} \\
& +\beta_{11} E O I_{i t}+\beta_{12} l F D I_{i t}+\beta_{13} l F D I_{i t} * \operatorname{Ddea}(x)_{-} W \\
& +\beta_{14} \operatorname{Ddea}(x)_{-} W+\beta_{15} T+v_{2 i j}
\end{aligned}
$$

where,

$$
\begin{aligned}
& I S I_{i t} \text { : dummy for ISI policy } \\
& E O I_{i t}: \text { dummy for EOI policy }
\end{aligned}
$$

$F D I_{i t}$ : Japanese FDI outflow in automotive industry to country $i$

$\operatorname{Ddea}(x)_{-} W$ : dummy of DEA as the exporting country

$l F D I_{i t} * \operatorname{Ddea}(x)_{-} W:$ interaction term 


$$
\begin{aligned}
& \mathrm{T}: \text { time effects } \\
& v_{2 i j} \quad: \text { error term. }
\end{aligned}
$$

while the gravity model for import models became:

$$
\begin{aligned}
\ln M_{i j} & =\alpha+\beta_{1} l G D P_{i}+\beta_{2} l G D P_{j}+\beta_{3} l D i s_{i j}+\beta_{4} l P C Y_{i}+\beta_{5} l P C Y_{j} \\
& \left.+\beta_{6} l\left|\Delta P C Y_{i j}\right|\right)+\beta_{7} B O R_{i j}+\beta_{8} L A N_{i j}+\beta_{9} F T A_{i j t}+\beta_{10} I S I_{i t}+\beta_{11} E O I_{i t} \\
& +\beta_{12} l F D I_{i t}+\beta_{13} l F D I_{i t} * \operatorname{Ddea}(m)_{-} W+\beta_{14} \operatorname{Ddea}(m)_{-} W \\
& +\beta_{15} T+v_{3 i j}
\end{aligned}
$$

where,

$\operatorname{Ddea}(m)_{-} W \quad$ : dummy of DEA as the exporting country

$l F D I_{i t} * D d e a(m)_{-} W:$ interaction terms

$v_{3 i j}:$ error term.

and the rest of variables and parameter symbols is defined as in above equations.

\subsection{Estimation Framework}

In this study, we faced a problem of zero trade flows when estimating our panel data. To overcome that problem, we took the approach of discarding the zero trade values from the sample. This approach is appropriate because these zero values would be undefined when we estimated using a log-linear model. In order to identify the presence of heteroscedasticity in our models we used Breusch-Pagan test. At the same time, we used variance inflation factor (VIF) and tolerance to identify the presence of multicollinearity. A VIF of 10 and above or a tolerance less than 0.10 indicates a multicollinearity problem. Our model was estimated using least squares Dummy Variable (LSDV) where the country dummies are used to capture country-specific fixed effects and time dummies ( $\mathrm{T}$ ) to capture time-specific effects. By adding country effects and time effect in the model we can mitigate the possibility of endogeneity bias (Wooldrige, 2002; Mohammed, 2017). In addition, we choose the LSDV rather than the "within" estimator because our data contain time-invariant variables such as distance, dummy of common border and dummy of language which would be dropped when regressing using the "within" estimator.

\section{Estimation Results}

Tables 3, 4 and 5 present the estimation results from basic OLS models, augmented traditional OLS models and augmented LSDV models for auto P\&C and final automobiles. The first and second columns in each table report the results for exports and imports of auto $\mathrm{P} \& \mathrm{C}$, while the third and fourth column report the results for exports and imports of final automobiles. In each model we used robust standard error due to the presence of heteroskedasticity and autocorrelation problems. The values of variance inflation factor (VIF), tolerance and pair-wise correlation clearly indicate that there is no serious multicollinearity issue in each model. With R-squared above 0.50 in each model, the gravity models explain more than half of the bilateral exports and imports of both auto $\mathrm{P} \& \mathrm{C}$ as well as final automobiles.

\subsection{Regression Results and Discussion}

Based on our results, the coefficient of GDPs (i.e. for countries $i$ and $j$ ) in export and import models for both auto $\mathrm{P} \& \mathrm{C}$ have, and the final automobiles have, the expected positive sign and are significant at 1 per cent level. In addition, robustness of the results of GDPs may be seen when the coefficient of GDPs in all models did not change significantly across specification. (see Tables $3-5$ ). This means that trade in auto P\&C and final automobiles between the East Asian countries and their trading partners could rise significantly if both parties experienced strong economic growth. Interestingly, the coefficients of GDPs between exports and imports as well as between auto P\&C and final automobiles, however, seemed to be heterogeneous. As can be seen in Tables 3-5, the magnitudes of $G D P_{i}$ in the export models are slightly greater than those in the import models. On the other hand, the magnitudes of $G D P_{j}$ in the import models are slightly greater than those of in the export models. This implies that export of both auto 
$\mathrm{P} \& \mathrm{C}$ and final automobiles depends more on $G D P_{i}$ than on the $G D P_{j}$, while imports of both products depend more on $G D P_{j}$. Therefore, we can say that the larger economies such as Japan and the Republic of Korea tend to export more auto $\mathrm{P} \& \mathrm{C}$ and/or final automobiles to smaller economies such as Thailand, the Philippines and Vietnam than they import from them. At the same time, smaller economies tend to import more auto $\mathrm{P} \& \mathrm{C}$ and/or final automobiles from larger economies than they export to them and this indicates that smaller economies seem to struggling to support their domestic automobile industry.

As expected, distance has a negative and significant effect on export and import for both auto $\mathrm{P} \& \mathrm{C}$ and final automobile models. This means that transport and transaction costs are an important determinant of trade flow and East Asian countries trade less with countries that are far away from them. Therefore, any policy that reduces trade costs will enhance trade of auto $\mathrm{P} \& \mathrm{C}$ and final automobiles. As seen in Tables 3-5, the coefficients of distance are larger in the case of auto $\mathrm{P} \& \mathrm{C}$ compared to final automobiles. The differences would be due to a greater sensitivity to costs in production process as reflected in the local nature of production networks compared to the global market for final automobiles.

In the case of auto $\mathrm{P} \& \mathrm{C}$, per capita income may represent superior transportation and communication infrastructure (such as better ports, road, airports, telephone lines, internet access, etc.) in a country (Head, 2003). Meanwhile, in the case of final automobiles, per capita income may represent the purchasing power of consumers and sophistication of consumer tastes in richer countries for imports of global brands of cars relative to local model. Based on the results, per capita income in both country $i$ and countryj has a positive sign and is significant at least at 5 percent level in almost all models. This indicates that an increase in transportation and communication quality in county $i$ and its partners as well as an increase in purchasing power and sophistication of consumer tastes in richer countries could facilitate trade in auto $\mathrm{P} \& \mathrm{C}$ and final automobiles between the countries under study. The coefficients on absolute in per capita differences are significant statistically in almost all models with negative sign and these results support the Linder hypothesis. This hypothesis says that the countries with similar the factor endowments, will trade more with each other compared to the countries with dissimilar demand. Therefore, these results would suggest that trade in auto products between Japan and the United States might be greater than the trade in those products between Japan and Vietnam.

The results also show that the coefficients of common language are significant statistically and have the anticipated positive sign in both export and import models for auto P\&C. On the other hand, the coefficients of common border are found to be insignificant in determining exports and imports for both auto $\mathrm{P} \& \mathrm{C}$ and final automobiles. Meanwhile, coefficients of FTA have positive sign and are significant statistically in the export models and in the import model of auto P\&C. This indicates that bilateral trade between East Asian countries and their partners increases when both are members of an FTA. The estimated coefficients for export and import of auto P\&C are 1.144 and 1.261 respectively. This means that trade flows of auto $\mathrm{P} \& \mathrm{C}$ with a member of a particular FTA are more than three times as much as those with a non-member. (Note 10) In the case of final automobiles, the estimated coefficient for export is 0.504 , which means that export flows of final automobiles with a member of a particular FTA are almost two times [exp $(0.504)=1.655]$ as much as those with a non-member. These results also indicate that FTA stimulates more trade in auto P\&C compared to trade in final automobiles.

As we anticipated in the previous chapter, government policies and programmes which is proxies by ISI and EOI policies seem to be an important determinant for the development of a country's trade of automobiles. Based on the results, ISI policies have the expected positive effect on the imports of auto P\&C. On the export side, however, ISI policies have a negative impact on both auto $\mathrm{P} \& \mathrm{C}$ and final automobiles (cf. Table 5). These results imply that in the case of automobile, ISI development strategy increases imports of East Asia's auto P\&C for the internal market use. Nevertheless, there is no statistical evidence showing the effect of this strategy to the imports of final automobiles. In addition, results in Table 5 also indicate that EOI policies affect the exports of auto $\mathrm{P} \& \mathrm{C}$ and final automobiles positively. This means that EOI strategy stimulate exports of East Asia's auto P\&C and final automobiles. Based on these results, one can conclude that government measures in supporting the automotive industry, such as by reducing tariff rates, providing subsidised loans, tax exemptions and expanding infrastructure and industrial estates, have managed to develop that industry and thus increase exports. 
Table 2. Basic model (OLS)

\begin{tabular}{|c|c|c|c|c|}
\hline \multirow{2}{*}{$\begin{array}{c}\text { Explanatory } \\
\text { Variables }\end{array}$} & \multicolumn{2}{|c|}{ Auto P\&C } & \multicolumn{2}{|c|}{ Final Automobiles } \\
\hline & Log of exports & Log of imports & Log of exports & Log of imports \\
\hline Constant & $-30.54 * * *$ & $-31.22 * * *$ & $-28.93 * * *$ & $-27.16^{* * *}$ \\
\hline$l G D P_{i t}$ & $1.337 * * *$ & $0.587 * * *$ & $1.567 * * *$ & $0.334 * * *$ \\
\hline$l G D P_{j t}$ & $0.767 * * *$ & $1.702 * * *$ & $0.100 * *$ & $1.503 * * *$ \\
\hline$l D i s_{i j}$ & $-1.221 * * *$ & $-1.763 * * *$ & -0.028 & $-0.821 * * *$ \\
\hline No of Obs. & 3697 & 3367 & 2576 & 2583 \\
\hline$R^{2}$ & 0.515 & 0.503 & 0.377 & 0.403 \\
\hline Adjusted $R^{2}$ & 0.514 & 0.502 & 0.376 & 0.402 \\
\hline$F$ & $1479.47 * * *$ & $1325.47 * * *$ & $789.86^{* * *}$ & $725.74 * * *$ \\
\hline$R M S E$ & 2.090 & 2.198 & 2.985 & 2.343 \\
\hline
\end{tabular}

Notes: $* * *, * *$ and $*$ denote as significance at 1 percent, 5 percent and 10 percent respectively.

Table 3. Augmented Traditional Model (OLS)

\begin{tabular}{lllll}
\hline \multicolumn{1}{c}{$\begin{array}{c}\text { Explanatory } \\
\text { Variables }\end{array}$} & \multicolumn{3}{c}{ Auto P\&C } & \multicolumn{2}{c}{ Final Automobiles } \\
\cline { 2 - 5 } & \multicolumn{1}{c}{ Log of exports } & \multicolumn{1}{c}{ Log of imports } & \multicolumn{1}{c}{ Log of exports } & Log of imports \\
\hline Constant & $-33.77^{* * *}$ & $-33.98^{* * *}$ & $-17.12^{* * * *}$ & $-24.79^{* * *}$ \\
$l G D P_{i t}$ & $1.174^{* * *}$ & $0.490^{* * *}$ & $0.724^{* * *}$ & $0.319^{* * * *}$ \\
$l G D P_{j t}$ & $0.798^{* * *}$ & $1.737^{* * *}$ & $0.091^{* *}$ & $1.400^{* * *}$ \\
$l D i s_{i j}$ & $-0.891^{* * *}$ & $-1.630^{* * *}$ & $-0.181^{* * *}$ & $-1.256^{* * *}$ \\
$l P C Y_{i t}$ & $0.458^{* * *}$ & $0.312^{* * *}$ & $1.433^{* * *}$ & $0.102^{* * *}$ \\
$l P C Y_{j t}$ & $-0.071^{* *}$ & $0.200^{* * *}$ & $0.134^{* * *}$ & $0.7411^{* * *}$ \\
$\left|\Delta P C Y_{j i t}\right|$ & $0.566^{*}$ & $-0.144^{* * *}$ & $-0.273^{* * *}$ & $-0.338^{* * *}$ \\
$B O R_{i j}$ & -0.276 & $-0.595^{*}$ & 0.435 & -0.406 \\
LNG $_{i j}$ & $0.756^{* * *}$ & $0.674^{* * *}$ & -1.281 & 0.027 \\
$F T A_{i j t}$ & $1.274^{* * *}$ & $1.177^{* * *}$ & $0.634^{* * *}$ & 0.224 \\
& & & & \\
No of Obs. & 3697 & 3367 & 2576 & 2583 \\
$R^{2}$ & 0.570 & 0.535 & 0.594 & 0.463 \\
Adjusted $R^{2}$ & 0.569 & 0.534 & 0.592 & 0.461 \\
$F$ & $612.15^{* * * *}$ & $493.66^{* * *}$ & $635.74 * * *$ & $298.21^{* * *}$ \\
RMSE & 1.968 & 2.129 & 2.414 & 2.223 \\
\hline
\end{tabular}

Notes: ***,** and * denote as significance at 1 percent, 5 percent and 10 percent respectively

Table 4. Augmented Model for period 1990-2015 (LSDV)

\begin{tabular}{lllll}
\hline \multirow{2}{*}{$\begin{array}{c}\text { Explanatory } \\
\text { Variables }\end{array}$} & \multicolumn{2}{c}{ Auto P\&C } & \multicolumn{2}{c}{ Final Automobiles } \\
\cline { 2 - 5 } & Log of exports & Log of imports & Log of exports & Log of imports \\
\hline Constant & $-16.800^{* * * *}$ & $-41.98^{* * *}$ & $-9.49^{* * * *}$ & $-26.08^{* * *}$ \\
$l G D P_{i t}$ & $0.967^{* * *}$ & $0.522^{* * *}$ & $0.526^{* * *}$ & $0.187^{* * *}$ \\
$l G D P_{j t}$ & $0.817^{* * *}$ & $1.745^{* * *}$ & $0.105^{* * *}$ & $1.418^{* * *}$ \\
$l D i s_{i j}$ & $-0.976^{* * *}$ & $-1.616^{* * *}$ & $-0.224 * *$ & $-1.271^{* * *}$ \\
$l P C Y_{i t}$ & $0.339^{* * *}$ & $0.437^{* * *}$ & $1.150^{* * *}$ & $0.169^{* *}$ \\
\hline
\end{tabular}




\begin{tabular}{|c|c|c|c|c|}
\hline$l P C Y_{j t}$ & $-0.055^{*}$ & $0.199 * * *$ & $0.293 * * *$ & $0.762 * * *$ \\
\hline$\left|\triangle P C Y_{i j t}\right|$ & 0.044 & $-0.136 * * *$ & $-0.249 * * *$ & $-0.347 * * *$ \\
\hline$B O R_{i j}$ & -0.087 & -0.637 & $0.665 * *$ & -0.450 \\
\hline$L N G_{i j}$ & $0.798 * * *$ & $0.694 * * *$ & -1.041 & 0.094 \\
\hline$F T A_{i j t}$ & $1.144 * * *$ & $1.261 * * *$ & $0.504 * *$ & 0.281 \\
\hline$I S I_{i t}$ & $-0.665 * * *$ & $0.180 *$ & $-1.150 * * *$ & 0.220 \\
\hline$E O I_{i t}$ & $0.769 * * *$ & $-0.281 * * *$ & $1.325 * * *$ & $-0.437 * * *$ \\
\hline$l F D I_{i t}$ & $-0.554 * * *$ & $0.314^{* *}$ & -0.015 & 0.239 \\
\hline$l F D I_{i t}{ }^{*} D d e a(x) \_W$ & $0.568 * * *$ & & $0.017 *$ & \\
\hline$l F D I_{i t}{ }^{*} D d e a(m) \_W$ & & -0.190 & & 0.053 \\
\hline
\end{tabular}

Country Dummies

$\begin{array}{lllll}\begin{array}{l}\text { Ddea }(x) \_W \\ \text { Ddea }(m) \_W\end{array} & -10.862 * * * & & -0.737 & \\ & & 3.914 & & 0.315 \\ \text { Time Dummies } & \text { YES } & \text { YES } & \text { YES } & \text { YES } \\ & 3697 & 3367 & 2576 & 2583 \\ \text { No of Obs. } & 0.617 & 0.540 & 0.621 & 0.480 \\ R^{2} & 0.615 & 0.538 & 0.620 & 0.478 \\ \text { Adjusted } R^{2} & 256.37 * * * & 164.51 * * * & 239.61 * * * & 107.71^{* * *} \\ F & 1.862 & 2.123 & 2.340 & 2.197 \\ \text { RMSE } & & & & \end{array}$

Notes: $* * * * *$ and $*$ denote as significance at 1 percent, 5 percent and 10 percent respectively

Specifically, results in Table 5 indicate that: first, ISI policies implemented by East Asian countries have increased their import of auto $P \& C$ at least 1.2 times [exp $(0.180)=1.197]$. Second, EOI policies towards the auto industry in East Asia have managed to increase the exports of auto parts, components and automobiles in that region. In the case of final automobiles, EOI policies have led to an increase in East Asia's exports by as much as nearly four times [exp $(1.325)=3.762$ ], while for auto $\mathrm{P} \& \mathrm{C}$, EOI policies have contributed to an increase in exports of two times [exp $(0.769)=2.158]$. This finding seems to suggest that EOI policies implemented by many East Asian countries facilitating FDI where Japanese automaker leading to import auto P\&C for either intermediate input production plants (e.g. in the Philippines) or final assembly plant (e.g. in Thailand). In the case of Thailand, EOI policies and industrialisation strategies led to the expansion of the Japanese FDI in automotive sector to that country (Note 11). This in turn, led to the increase in the export of auto P\&C from Japan to Thailand (Asia Monitor Resource Centre, 2011).

Even though countries' strategies towards developing their automobile industry in this region vary from one country to another, it is obvious that governmental policies are crucial to ensuring that East Asia's automobile industry achieves competitiveness and has comparative advantage in that industry. Thailand and the Philippines, lacking a "national car programme", seem to shift their policies from ISI to EOI and focus on their cross-border corporation with foreign automakers, particularly from Japan. Governments have introduced various measures, such as tax reductions on imports and exports, lifting of restrictions on the import of $\mathrm{P} \& \mathrm{C}$, liberalisation schemes and the removal of import bans and tariff protection for domestic manufactured products to make these countries attractive for automotive investment. On the other hand, the Republic of Korea, Malaysia and Indonesia have implemented a different strategy from Thailand and the Philippines. These countries focus more on their "national car" model into which they have directed and put very large resources directly or indirectly into a single automobile company. In the case of Malaysia, a high import duty and local content policies has been imposed to protect the "national car". In addition, a single manufacturer has also been encouraged, and in the case of the Republic of Korea the competition between automobile manufactures has been controlled.

Similar with government policies and programmes, Japanese MNCs have also played a pivotal role in boosting auto trade in the East Asian region, as well as helping many countries in the region to develop their own automobile 
industry. In fact, the role of these two factors may be complementary in that government policies facilitating FDI with both necessary for development of automobile industry in the East Asia.In addition, they are also considered one of the important determinants for the development of East Asian countries' position in the international production chain of the automobile industry.

In equations (7) and (8) we include FDI and its interaction with DEA. Based on the interaction analysis, we can divide the impact of Japanese FDI outflow into two categories i.e., impact to the export of DEA's auto P\&C (as well as final automobiles) and the impact on the export of Japanese auto P\&C as a base category (final automobiles).

Table 6. Summary Results for log of $\mathrm{FDI}_{\mathrm{it}}$ and the Interaction Variables

\begin{tabular}{|c|c|c|c|}
\hline \multicolumn{2}{|c|}{ Model } & Main effect of lFDI & Interaction effects* \\
\hline \multirow{2}{*}{ Export } & Auto P\&C & -0.554 & $-0.554+0.568=0.01$ \\
\hline & Final automobiles & -0.015 (insignificant) & $-0.015+0.017=0.002$ \\
\hline \multirow{2}{*}{ Import } & Auto P\&C & +0.314 & Irrelevant due to \\
\hline & Final automobiles & insignificant & $\begin{array}{l}\text { the insignificant of } \\
\text { interaction terms }\end{array}$ \\
\hline
\end{tabular}

Note: $(1) *$ Refer to the dummy of DEA (Ddea(x)_W = 1 if country $\mathrm{i}=$ China, Indonesia, Republic of Korea, Malaysia, The Philippines, Singapore, Thailand and Vietnam, while $=0$ if country $i=$ Japan.

(2) In the import model the dummy of DEA is Ddea(m)_W

Based on Table 5, we can see that from the export side in auto $\mathrm{P} \& \mathrm{C}$, the interaction term, lFDI*Ddea_W is statistically significant with a positive sign. These results indicate strong evidence in these data that the Japanese FDI outflow to DEA has a different effect on the exports of Japan and DEA. Nonetheless, as indicate in Table 6 the magnitude of the different effect is too small (i.e., equals 0.01). Therefore, we conclude that when the outflow of Japanese FDI to DEA increase, the export of DEA's auto P\&C to the world did not greater than the export of Japanese auto P\&C worldwide. This finding is in line with Nishitateno (2012) who found that there is a complementary relationship between FDI and Japanese export of auto P\&C.

Likewise, in the case of final automobiles, Table 5 also shows that interaction term, $l F D I * D d e a \_W$ is statistically significant. Again, even though these results indicate the strong evidence of the Japanese FDI outflow to DEA has a different effect on the exports of Japan and DEA, but the magnitude of that interaction term is too small (i.e., equals 0.002). Therefore, in the case of final automobile we can again conclude that when the outflow of Japanese FDI to DEA increase, the export of DEA's final automobiles to the world did not greater than the export of Japanese final automobiles worldwide. Meanwhile, from the import perspective, interaction terms in import models are insignificant. This implies the absence of evidence that Japanese FDI outflow to DEA has a different effect on Japanese imports and import of DEA.

\section{Conclusion}

The objective of this study is to investigate empirically the factors that determine the level of automobile trade of East Asian countries given their position in the international production chain. The study also intends to examine how important the role of government policies and the role of Japanese Multinational Corporations (MNCs) to the development of East Asia's countries position in the international production chain in that industry. In addition, the impact of Japanese FDI outflows to the developing East Asia will also been investigated.

Results in this study are consistent with standard model. In general, we found that GDPs, distance, per capita income, FTA, government policies, language and FDI are the determinants for the development of automobile industry in each country in East Asia. In the case of auto P\&C, apart from economic size, the role of government through trade policy (i.e., FTA) and industrial policies as well as the role of MNCs are the major contributors to the development both exports and imports of East Asian countries. In the case of final automobiles, the role of FTA and language seems to be unimportant. Nonetheless, the role of government policies and MNCs seem to be important.

Government policies played pivotal role in encouraging foreign direct investment into many East Asian countries. Accordingly, many East Asian countries have conducted friendly investment incentives policies such as tax holidays on corporate income, import duty exemption on intermediate products, land ownership rights for foreign investors, permission to bring in foreign experts and technicians etc. in order to attract MNCs particularly from Japan to invest 
in their countries. In general, Japan's direct investment to East Asia continued to increase over time. For instance, the total amount of investment to East Asia in 2004 was US\$ 10.4 billion and this figure jumped to about US\$17.0 billion in 2008 (JETRO website). Japanese investments in China and Thailand (Note 12) were high consistently, while other countries experienced investment increase in a specific year, such as Malaysia in 2006, Singapore in 2007 and Rep. of Korea in 2008 (AMRC, 2011).

Japanese MNCs play an important role in the development of East Asia's production networks and they in turn has boosted intra-regional as well as inter-regional in this region. In this respect, Japanese MNCs make use of brand-to-brand complementation scheme and ASEAN industrial corporation scheme to implement division of labour in this region. For example, Toyota make use of these two schemes to produce diesel engines in Thailand, steering gears in Malaysia, transmission systems in the Philippines and gasoline engines in Indonesia (Guiheux, 1999). Although Japanese MNCs have developed the automobile industry in many Asian countries (especially Thailand and the Philippines) as the centre of production for its auto P\&C and final automobiles, Japan is still becomes the region's major exporter of those products. In other words, even though other East Asian countries have achieved a rapid development in their automobile industry, they are still unable to compete with Japan in terms of the value export of automobile products.

\section{References}

Aldulaimi, S.H. (2018). The Influence of National Culture on Commitment that Produce Behavioral Support for Change Initiatives. International Journal of Applied Economics, Finance and Accounting, 3(2), 64-73.

Anderson, J.E. (1979). A Theoretical Foundation for the Gravity Equation. The American Economic Review, 69(1), 106-116.

Anderson, J.E., \& Wincoop, E.V. (2003). Gravity with Gravitas: A Solution to the Border Puzzle. The American Economic Review, 93(1), 170-192.

Athukorala, P.-C. (2010). Production Networks and Trade Patterns in East Asia. Working Paper Series on Regional Economic Integration No. 56, Asian Development Bank.

Athukorala, P.-C., \& Menon, J. (2010). Global Production Sharing, Trade Patterns, and Determinants of Trade Flows in East Asia. ADB Working Papers Series on Regional Economic Integration No. 41, Asian Development Bank.

Athukorala, P.-C., \& Yamashita, N. (2006). Production Fragmentation and Trade Integration: East Asia in a Global Context. North American Journal of Economics and Finance, 17(3), 233-256.

Ballasa, B. (1981). The Newly Industrializing Countries in the World Economy. New York, Pergamon Press.

Bergstrand, J.H. (1985). The Gravity Equation in International Trade: Some Microeconomic Foundations and Empirical Evidence. The Review of Economics and Statistics, 67, 474-481.

Bergstrand, J.H. (1989). The Generalised Gravity Equation, Monopolistic Competition, and the Factor Proportion Theory in International Trade. Review of Economics and Statistics, 71(1), 143-153.

Bruton, H. (1989). Import Substitution. In Chenery, H., \& Srinivasan, T. N. (Eds.), Handbook of Development Economics. Amsterdam, North Holland: Elsevier Science Publishers.

CHE, G.N., \& Sundjo, F. (2018). Determinants of Female Labour Force Participation in Cameroon. International Journal of Applied Economics, Finance and Accounting, 3(2), 88-103.

Cheng, I.-H., \& Wall, H.J. (2005). Controlling for Heterogeneity in Gravity Models of Trade and Integration. Federal Reserve Bank of St. Louis Review, 87(1), 49-63.

Christie, E. (2002). Potential Trade in Southeast Europe: A Gravity Model Approach. Working Paper, The Vienna Institute for International Economic Studies-WIIW.

Clark, D.P. (2010). Vertical Specialization with Developed and Developing Countries. Journal of Developing Areas, 43(2), 327-339.

Deardorff, A.V. (1998). Determinants of Bilateral Trade: Does Gravity Work in a Neoclassical World?. In Frankel, J. A. (Ed.), The Regionalization of the World Economy. Chicago: University of Chicago Press.

Ernst, D. (1997), From Partial to Systemic Globalization: International Production Networks in the Electronics Industry. BRIE Working Paper No. 98, IBRIE.

Frankel, J.A., \& Wei, S.-J. (1998). Regionalization of World Trade and Currencies: Economics and Politics. In Frankel, J. A. (Ed.), The Regionalization of the World Economy. Chicago: University of Chicago Press. 
Fumio, K., \& Haruhi, T. (2011). Trends in Japan's Overseas Direct Investments and Their Impact on Asian Workers. Capital Mobility Research Paper Series No. 1, Asia Monitor Research Centre.

Guiheux, G. (1999, February). A Survey on the Current Investments of Japanese Auto Parts Industry in Asia: The Case of Toyota First Tier Suppliers. Actes du GERPISA: International Division Labour and Assembler-Supplier Relations, (25), 105-117.

Head, K. (2003). Gravity for Beginners. University of British Columbia.

Japan Auto Parts Industries Association. (2005). Japanese Automotive Parts Industry 2005. Tokyo: Automotive Parts Publishing Company.

JETRO website. Retrieved 15 September 2013, from http://www.jetro.go.jp/

Jokakuu, M.A. (2018). Assessing the Effectiveness of Management Consultancy in Operations of Construction Firms: A Case of Willy Enterprises Ltd in Arusha Tanzania. Asian Business Research Journal, 3, 26-32.

Kang, M., Kim, H.H., Lee, H., \& Lee, J. (2010). Regional Production Networks, Service Off shoring, and Productivity in East Asia. Japan and the World Economy, 22(3), 206-216.

Karunaratne, N.D. (1980, September/October). Export Oriented Industrialisation Strategies. Intereconomica, 5, 217-223.

Kimura, F. (2006). International Production and Distribution Networks in East Asia: Eighteen Facts, Mechanics and Policy Implications. Asian Economic Policy Review, 1(2), 326-344.

Kimura, F. (2008). Does International Fragmentation Occur in Sectors Other Than Machinery?. Asian Economic Journal, 22(4), 343-358.

Kimura, F., \& Obashi, A. (2010). International Production Networks in Machinery Industries: Structure and Its Evolution. ERIA Discussion Paper Series No. 2010-09, ERIA.

Kimura, F., \& Obashi, A. (2011). Production Networks in East Asia: What We Know So Far. ADBI Working Papers No.320, Asian Development Bank Institute.

Linnemann, H. (1966). An Econometric Study of International Trade Flows. Amsterdam, North-Holland.

Mohammed, Z. (2017). Impact of Sexual Lifestyle on Hormone-Related Health Decline Case Married Teachers. International Journal of Social Sciences Perspectives, 1(1), 1-5.

Nishitateno, S. (2012). Global Production Sharing and the FDI-Trade Nexus: New Evidence from the Japanese Automobile Industry. Working papers in Trade and Development No.2012/013, ANU Collage of Asia and the Pacific.

Okon, E.O. (2017). Climate Change: Space Technology and Climate-Resilient Development in Nigeria. International Journal of Social Sciences Perspectives, 1(1), 6-19.

Pöyhönen, P. (1963). A Tentative Model for the Volume of Trade between Countries. Weltwirtschaftliches Archiv, 90(1), 93-100.

Shafai, N.A., Nassir, A.M., Kamarudin, F., Rahim, N.A., \& Ahmad, N.H. (2019). Dynamic Panel Model of Dividend Policies: Malaysian Perspective. Contemporary Economics, 13(3), 239-252.

Shafaeddin, M., \& Pizarro, J. (2007). From Export Promotion to Import Substitution: Comparative Experience of China and Mexico. MPRA Paper No. 6650, Munich Personal RePEc Archive.

Shepherd, B. (2010). Trade Costs and Facilitation in APEC and ASEAN: Delivering the Goods?. MRPA Paper No. 2153, Munich Personal RePEc Archive.

Shimukawa, K. (2010). Japan and Global Automotive Industry. United Kingdom, Cambridge University Press.

Song, H. (2012). New Challenges to the Export Oriented Growth Model. In Zhang, Y., Kimura, F., \& Oum, S. (Eds.), Moving toward a New Development Model for East Asia: The Role of Domestic Policy and Regional Cooperation, ERIA Research Project Report 2011-10. Jakarta: ERIA.

Stanciu, S., Bichescu, C., Capatina, A., Dragan, G.B., \& Florea, A.M. (2018). Enablers and inhibitors of collaborative network development in organic food industry: A fuzzy set qualitative comparative analysis (fsQCA). Contemporary Economics, 12(4), 433-446.

Tinbergen. (1962). Shaping the World Economy: Suggestions for an International Economic Policy. The Twentieth 
Century Fund. New York.

UN Comtrade database. Retrieved 5 January 2010, from http://comtrade.un.org/

Wooldridge, J.M. (2006). Introductory Econometrics: A Modern Approach (3rd ed.). USA: Thomson Higher Education.

Zhang, W.B. (2018). Growth, Residential Distribution, and Land Price in an Integrated Solow's Growth and Alonso’s Residential Model. Asian Themes in Social Sciences Research, 2(1), 23-31.

\section{Notes}

Note 1. For example in Nopprach (2009) and Farrell \& Findley (2001)

Note 2. The gravity model has been widely used in empirical studies of international economics.

Note 3 . Since then, the theoretical studies on gravity model have been continued by other authors such as Helpman (1987), Bergstrand (1989), Deardorff (1998), and Anderson and Wincoop (2003).

Note 4. Each pair of trading country (country i and its partner i.e., country j) are included separately.

Note 5. For example, Frankel \& Wei (1998) and Athukorala\& Yamashita (2006)

Note 6. The proponents of ISI strategy argued that the contribution of that strategy to the industrialisation is by mean of "learning by doing" (Shafaedin and Pizarro, 2007)

Note 7. EEI=exports of both auto P\&C and final automobiles / total trade of both auto P\&C and final automobiles

Note 8. Athukorala and Yamashita (2006) defined DEA as East Asia excluding Japan. In this study, countries included as the DEA are Republic of Korea, China, Thailand, Indonesia, the Philippines, Malaysia, Singapore and Vietnam

Note 9. We excluded relative labour costs in our model due to the lack of data.

Note 10. $\exp (1.158)=3.184$ and $\exp (1.206)=3.340$.

Note 11. FDI in automotive sector into Thailand increased well over 15 percent between 2007 and 2009 and more than half of the FDI came from Japan (Asia Monitor Research Centre, 2011).

Note 12. Although Thailand has experienced devastating flood at the end of 2011, many Japanese automobile enterprise have announced their intensions to continue investments in Thailand in early 2012. 